\title{
LAMPU PJU OTOMATIS
}

\section{AUTOMATIC PJU LIGHTS}

\author{
Sutono $^{1 *}$, M F Wicaksono ${ }^{2}$ \\ 1)Program Studi Sistem Komputer, Fakultas Teknik dan Ilmu Komputer, Universitas Komputer Indonesia \\ Jl. Dipati Ukur No. 112 - 116, Bandung, Indonesia 40132 \\ 2)Program Studi Teknik Komputer, Fakultas Teknik dan Ilmu Komputer, Universitas Komputer Indonesia \\ Jl. Dipati Ukur No. 112 - 116, Bandung, Indonesia 40132 \\ *email: sutono@email.unikom.ac.id
}

\begin{abstract}
The purpose of this study is to assist the Government in overcoming the energy crisis, especially the problem of Public Road Lighting. In big cities it is very dominant to find a PJU lamp which is indeed a vital public facility, especially at night. The more placement points of PJU lights will certainly have an energy crisis, although there is a way to replace LED lights as a solution to overcome the energy crisis. on this basis the Researcher designed a PJU lamp with a solar cell power source to reduce the burden of the PLN which was already large enough to meet the electricity needs in big cities such as Jakarta, Bandung, Surabaya and other cities in Indonesia. So that these goals can be fulfilled, then the design of this tool uses a multi sensor so that the PJU lights turn on at night and there are objects around the PJU lights.
\end{abstract}

Keywords - solar cell, lights, ultrasonic, led, PJU, automatic

\begin{abstract}
ABSTRAK - Tujuan dari penelitian ini untuk membantu Pemerintah dalam mengatasi krisis energi, terutama masalah Penerangan Jalan Umum. Di kota besar sangat dominan di temui lampu PJU yang memang merupakan sarana umum yang sangat vital terutama pada malam hari. Semakin banyak titik penempatan lampu PJU tentunya akan berdampak krisis energi walaupun ada suatu cara dengan mengganti lampu LED sebagai solusi dalam mengatasi krisis energi. atas dasar inilah Peneliti membuat rancangan lampu PJU dengan sumber listrik solar sel untuk mengurangi beban PLN yang sudah cukup besar dalam memenuhi kebutuhan listrik di kota besar seperti Jakarta, Bandung, Surabaya dan kota lainnya di Indonesia. Agar tujuan tersebut dapat terpenuhi, maka pada rancangan alat ini menggunakan multi sensor sehingga lampu PJU menyala pada malam hari dan terdapat objek di sekitar lampu PJU tersebut.
\end{abstract}

Kata Kunci - solar sel, lampu, ultrasonik, led, PJU, otomatis

\section{Pendahuluan}

Di era modern ini masyarakat khususnya yang tinggal di kota-kota besar telah menggunakan lampu penerangan otomatis. Lampu otomatis ini dilengkapi dengan multi sensor untuk efisiensi penggunaan dan pemakaian energi listrik[1]. Pengaturan intensitas cahaya lampu didasarkan pada cahaya ambien seperti cahaya matahari. Auto switch dan auto illumination digunakan untuk pemborosan pemakaian energi listrik untuk sistem penerangan[2]. Seperti halnya pada tulisan Street lighting in smart cities: A simulation tool for the design of systems based on narrowband PLC yang dibut oleh Sittoni, dan kawan- kawan[3] dan Smart Lighting in Multipurpose Outdoor Environments: Energy Efficient Solution using Network of Cooperating Objects yang dibuat oleh Anna Florea, dan kawan-kawan[4], mereka membuat Smart Lighting dengan teknologi pencahayaan yang dapat dikontrol secara otomatis terhadap keberadaan obyek dan intensitas cahaya, dan lain-lain. Tujuan dari multi sensor untuk saling menutupi kelebihan dan kekurangan masing-masing sehingga dapat mengantisifasi terhadap pemicu palsu (false triggers) [5].

Lampu PJU Otomatis berbasis solar sel ini merupakan pengembangan dari beberapa peneliti yang telah dilakukan[1]-[5] dengan cara 
menambahkan fitur pemakaian solar sel untuk mengatasi penghematan energi sesuai dengan program pemerintah tahun 2016. Kementrian Energi dan Sumber Daya Mineral (ESDM) menginisisasi gerakan hemat energi "Potong 10\%". Gerakan ini merupakan aksi bersama melibatkan Pemerintah, pelaku bisnis/industri, Organisasi Masyarakat Sipil dan individu untuk melakukan penghematan energi sebesar 10\%. Gerakan ini dilatarbelakangi dengan pesatnya pertumbuhan kons msi energi di tengah penurunan jumlah cadangan energi fosil yang saat ini masih menjadi sumber utama energi listrik di Indonesia.

\section{METODE DAN BAHAN}

Lampu LED Pintar berbasis solar sel dan multi sensor merupakan lampu penerangan dengan bahan utama $L E D$ ) sebagai sumber penerangan jalan serta multi sensor untuk auto switch dan auto illumination. LED dan multi sensor sudah terintegrasi dan dikemas dengan desain sesuai kebutuhan secara otomatis dengan kondisi cahaya ambien dan aktivitas disekitarnya.

Multi sensor yng digunakan adalah sensor gerak, sensor Ultrasonik dan sensor cahaya. Sensor gerak merupakan sebuah sensor berbasiskan inframerah. Sensor ini hanya merespon energi dari pancaran sinar inframerah pasif yang dimiliki oleh setiap benda yang terdeteksi olehnya, umumnya tubuh manusia[6]. Sensor gerak dirancang khusus untuk deteksi manusia hal ini karena sensor ini peka terhadap gelombang panas manusia (8 - 14 meter). Sensor gerak terdiri dari dua sensor inframerah, sehingga mampu mendeteksi perubahan suhu manusia dan suhu lingkungan ketika manusia melakukan gerakan[7]. Sensor cahaya yang digunakan dalam penelitian ini menggunakan IC opamp LM324 yang difungsikan sebagai rangkaian pembanding (comparator) dengan membandingkan intensitas cahaya matahari yang mengenai permukaan $L D R$ dengan tegangan referensi yang dapat diatur sesuai dengan kebutuhan. Bentuk dan wujud multi sensor yang digunakan dapat dilihat pada gambar 1 .

Penggabungan dari kedua sensor bertujuan untuk mengatasi kekurangenan dari kedua sensor tersebut sehingga dapat mencegah terjadinya false off dan false on. False off adalah kelemahan dari sensor gerak dimana sensor ini akan off ketika masih ada obyek (manusia) disekitar area sistem yang dideteksi, sedangkan false on adalah kelemahan dari sensor ultrasonik dimana sensor tersebut akan on ketika ada gerakan yang bukan berasal dari gerakan manusia. Sensor LDR merupakan sensor cahaya yang digunakan untuk mengatur intensitas pencahayaan yang dibutuhkan untuk auto illumination dengan memperlihatkan cahaya ambien atau cahaya disekitar area sistem yang dideteksi.

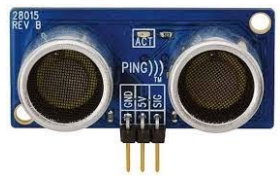

(a) Sensor Ultrasonik/PING

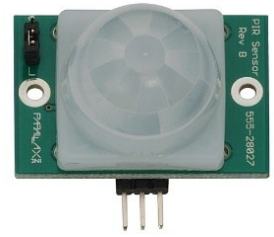

(b) Sensor Gerak/PIR

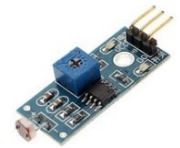

(c) Sensor cahaya LDR

Gambar 1. Bentuk dan Wujud Multi Sensor

Lampu PJU (Penerangan Jalan Umum) tenaga surya (solar sel) berbasis LED menggunakan daya yang lebih sedikit. PJU solar sel tidak membutuhkan kabel listrik. Sangat cocok untuk daerah-daerah yang jauh dari jangkauan listrik, instalasi kabel listrik menjadi tidak ekonomis dan kemudahan instalasi. Beberapa pertimbangan penggunaan lampu jalan berbasis solar sel antara lan: (1) daya tahan perangkat dan lampu LED, (2) tanpa jaringan kabel, bersifat mandiri menggunakan tenaga matahari, (3) tidak merusak fasilitas umum dengan penggalian kabel, (4) Tanpa perawatan, (5) instalasi sangat mudah, dan (6) kemudahan pemindahan. Lampu PJU yang digunakan dalam penelitian ini merupakan lampu PJU yang bentuknya dapat dilihat pada gambar 1 . Lampu jalan solar sel yang dibuat sistematis, fungsional dan efisien, karena tidak terdapat banyak peralatan pendukung lain seperti lampu jalan solar sel konvensional atau tipe lama dimana terdapat modul solar sel, baterai, box baterai, kontroller, lampu, kabel, dan lain-lain yang di pasang terpisah dan menyulitkan saat instalasi pemasangan. Sementara lampu jalan solar cell type all in one/integrated solar street semua komponen/material pendukung sistemnya di buat menjadi satu tertanam di dalam satu unit yang menempel pada kap lampunya. 


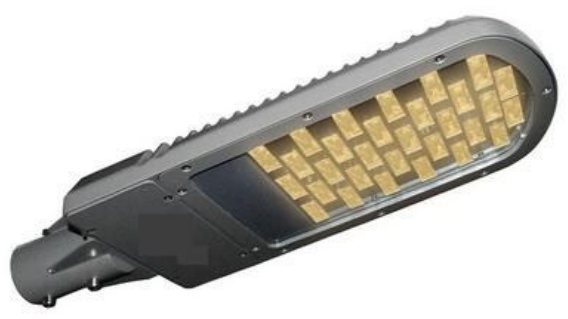

Gambar 2. Lampu PJU tenaga matahari

Sensor ultrasonik merupakan sensor yang dikembangkan oleh Paralax yang difungsikan untuk mengukur jarak dengan akurasi $2 \mathrm{~cm}$ hingga 3 meter. Bentuk fisik sensor ultrasonik dapat dilihat pada gambar 3.

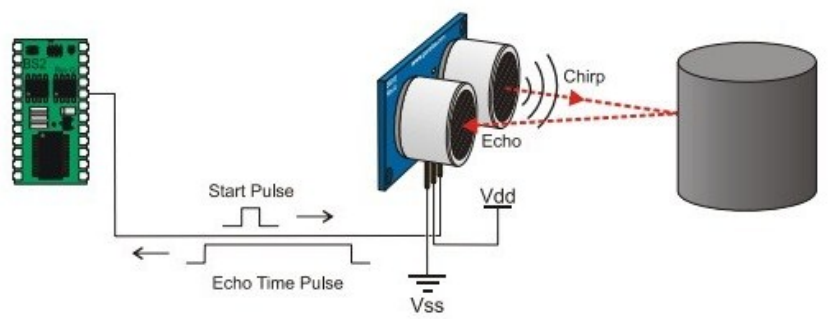

Gambar 3. Sensor ultrasonik

Namun ada beberapa kondisi dimana sensor ultrasonik tidak dapat membaca jarak secara akurat dalam beeberapa kondisi antara lain (1) Jarak objek yang dideteksi lebih dari 3 meter, (2) Posisi sensor dan permukaan objek membentuk sudut lebih dari 45 derajat sehingga pantulan sinyal ultrasonik tidak bisa diterima echo, (3) Dimensi objek yang dideteksi sangat kecil. Penggambaran konseptual sensor ultrasonik dapat dilihat pada gambar 4 .
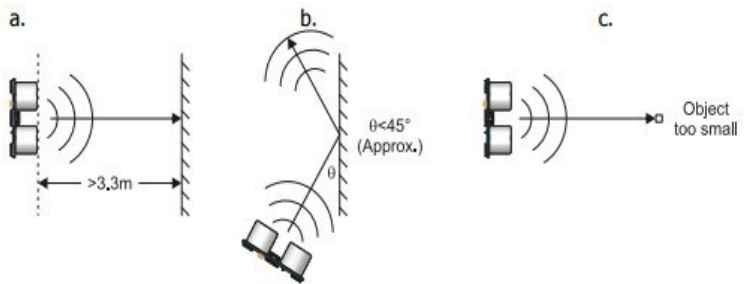

Gambar 4. Konseptual sensor ultrasonik

Cepat rambat suara atau umum disebut kecepatan suara (speed of sound) berbeda terhadap media rambatnya, bahkan pada udara pun berbeda terhadap suhu udaranya seperti terlihat pada tabel 1 dan tabel 2.
Tabel 1. Kecepatan suara pada media udara dengan suhu berbeda [8]

\begin{tabular}{rrrr}
\hline $\begin{array}{l}\text { Tempe- } \\
\text { ratur } \\
\mathrm{T}\left({ }^{\circ} \mathrm{C}\right)\end{array}$ & $\begin{array}{l}\text { Speed of } \\
\text { sound } \\
\mathrm{C}(\mathrm{m} / \mathrm{s})\end{array}$ & $\begin{array}{l}\text { Density } \\
\text { of air } \\
\mathrm{P} \\
\left(\mathrm{kg} / \mathrm{m}^{3}\right)\end{array}$ & $\begin{array}{l}\text { Characteristic } \\
\text { spesific } \\
\text { acoustic } \\
\text { impedance } \\
\mathrm{z}_{\mathrm{o}}(\mathrm{Pa}-\mathrm{s} / \mathrm{m})\end{array}$ \\
\hline 35 & 351,88 & 1,1455 & 403,2 \\
30 & 349,02 & 1,1644 & 406,5 \\
25 & 346,13 & 1,1839 & 409,4 \\
20 & 343,21 & 1,2041 & 413,3 \\
15 & 340,27 & 1,2250 & 426,9 \\
10 & 337,31 & 1,2466 & 420,5 \\
5 & 334,32 & 1,2690 & 424,3 \\
0 & 331,30 & 1,2922 & 428,0 \\
-5 & 328,25 & 1,3163 & 432,1 \\
-10 & 325,18 & 1,3413 & 436,1 \\
-15 & 322,07 & 1,3673 & 440,3 \\
-20 & 318,94 & 1,3943 & 444,6 \\
-25 & 315,77 & 1,4224 & 449,1 \\
\hline
\end{tabular}

Tabel 2. Kecepatan suara pada beragam media [9]

\begin{tabular}{llrr}
\hline Material & $\begin{array}{l}\text { Young's } \\
\text { modulus } \\
\left(\mathrm{N} \mathrm{m}^{-2}\right)\end{array}$ & $\begin{array}{r}\text { Density } \\
\left(\mathrm{kg} \mathrm{m}^{3}\right)\end{array}$ & $\begin{array}{l}\text { Speed } \\
\text { of } \\
\text { sound } \\
\left(\mathrm{ms}^{-1}\right)\end{array}$ \\
\hline Steel & $2,10 \times 10^{11}$ & 7.800 & 5.189 \\
Aluminium & $6,90 \times 10^{10}$ & 2.720 & 5.037 \\
Lead & $1,70 \times 10^{10}$ & 11.400 & 1.221 \\
Glass & $6,00 \times 10^{10}$ & 2.400 & 5.000 \\
Concrete & $3,00 \times 10^{10}$ & 2.400 & 3.536 \\
Water & $2,30 \times 10^{9}$ & 1.000 & 1.517 \\
Air (at 20 $\left.{ }^{\circ} \mathrm{C}\right)$ & $1,43 \times 10^{5}$ & 1,21 & 344 \\
$\begin{array}{l}\text { Beech wood } \\
\text { (along the }\end{array}$ & $1,40 \times 10^{10}$ & 680 & 4.537 \\
grain) & & & \\
$\begin{array}{l}\text { Beech wood } \\
\text { (across the }\end{array}$ & $8,80 \times 10^{10}$ & 680 & 1.138 \\
grain) & & & \\
\hline
\end{tabular}

Sensor gerak merupakan sensor yang bekerja dengan snyal infrared yang dipancarkan suatu onjek (dalam hal ini tubuh manusia) untuk kemudian dibandingkan dengan suhu ruangan. Sensor gerak dapat disebut sebagai Motion Sensor atau Pressense Detector. Secara umum, sensor hanya sensitif terhadap suhu tubuh manusia. Jika keberadaan manusia masuk dalam cakupan/coverage area 
sensor, maka suhu tubuh yang dipancarkan manusia akan dideteksi dan selanjutnya sensor akan aktif. Sensor bersifat pasif atau bersifat menerima sinyal infrared dari luar. Oleh karena itu, pada umumnya sensor gerak ini diperuntukan sebagai penggunaan di dalam ruangan karena apabila di luar ruangan (outdoor) perubahan suhu yang terjadi tidak hanya disebabkan dari panas tubuh manusia, melainkan bisa dari cuaca (sinar matahari). Jarak yang dapat dideteksi sensor gerak sekitar 3 - 4 meter kesamping dan 5- 7 meter ke depan dengan sudut yang dapat terdeteksi sekitar 110o, seperti yang diperlihatkan pada gambar 5 .
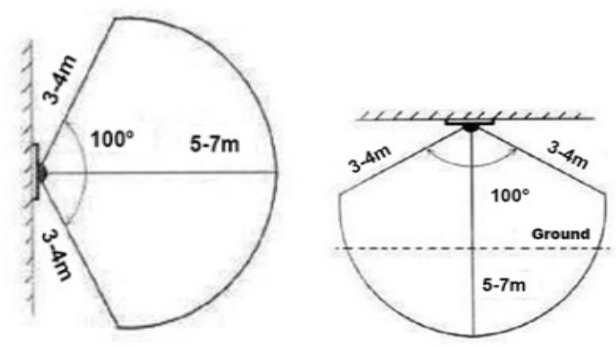

Gambar 5. PIR sensing angle

\section{HaSil DAN PEMbahasan}

Lampu penerangan jalan PJU solar sel yang digunakan memiliki spesifikasi: (1) Dimensi produk dengan ukuran panjang $40 \mathrm{~cm}$, lebar $21 \mathrm{~cm}$, (2) Konsumsi daya 20 watt, (3) Bahan material ABS (Acrylonitrile Butadiene Styrene), sejenis bahan polimer yang memiliki banyak aplikasi, karena kekuatan, mudahnya di bentuk dan harga yang murah, (4) Warna casing grey (5) Jumlah LED 20, (6) Ketinggian optimal 5 - 6 meter, (7) Aplikasi untuk jalan umum, (8) Include batere lithium 3,7 volt/9 Ah, (9) Waktu charge baterai 8 - 12 jam (optimal), (10) Daya panel surya 7 WP/ 6 volt dan (11) Durasi menyala sampai 9 jam.

Untuk mendapatkan disain yang baik, maka langkah awal penelitian dengan menetapkan tinggi tiang yang digunakan untuk lampu penerangan dengan asumsi tinggi tiang lampu PJU sekitar 2 meter dengan mengacu pada deskripsi dari lampu PJU tersebut.

Langkah berikutnya menentukan penempatan dari sensor PIR dan sensor Ultrasonik untuk mendeteksi keberadaan seseorang yang berada di area sistem tersebut. Dengan menggunakan petunjuk yang dijelaskan pada gambar 4, maka dapat diasumsikan bahwa bagian tubuh manusia yang akan dideteksi adalah badan/perut, karena pada bagian inilah yang memiliki permukaan data yang lebih baik dibandingkan dengan bagian tubuh yang lain seperti kaki, tangan dan kepala. Berdasarkan data WHO tinggi badan orang Indonesia yang ideal rata-rata sekitar 145 - 165 meter. Untuk ilustrasi tubuh manusia dapat dilihat pada gambar 6 . Berdasarkan data dari WHO dan ilustrasi gambar 6, maka dapat kita asumsikan tinggi sensor yang akan kita letakan dari dasar tiang PJU.

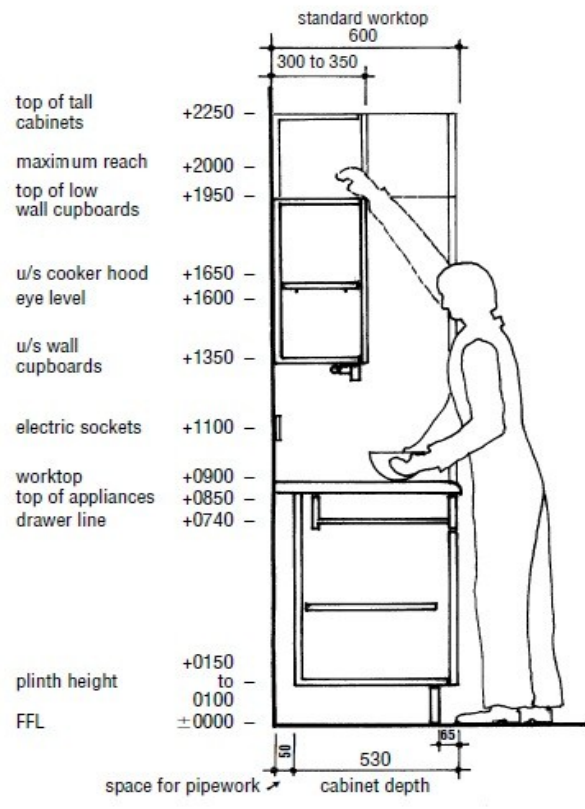

Gambar 6. Ilutrasi Tinggi

Langkah selanjutnya adalah membuat block area sebagai petunjuk deteksi objek saat akan menggunakan fasilitas PJU tersebut. Untuk lebih detilnya dapat dilihat pada gambar 7. Berdasarkan gambar 5 dan gambar 8, maka dapat ditentukan besar sudut a sekitar 40 derajat, dengan asumsi tinggi sensor sekitar 1 meter atau panjang ab = 1 meter. Maka berdasarkan rumus segitiga maka panjang/jarak bc dapat dihitung dengan rumus tan $40=\mathrm{bc} / \mathrm{ab}$ atau panjang bc sama dengan panjang $\mathrm{ab}$ dikalikan dengan tan 40. Tangen 40 derajat $=0,839$, sehingga panjang/jarak bc adalah $0,839 \times$ tinggi ac.

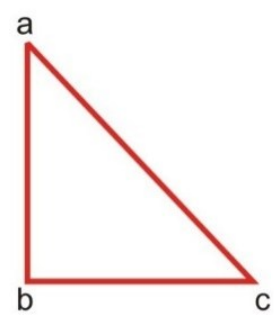

Gambar 7. Segitiga

Langkah terakhir adalah membuat tabel penelitian berdasarkan gambar 5, 6, 7 dan rumus segita, sehingga di dapat tabel pengamatan seperti yang ditunjukan pada tabel 3 . Dengan besar tangen sudut 40 derajat atau sekitar 0,839 . 
Tabel 3. Hasil perhitungan dengan rumus segitiga

\begin{tabular}{cr}
\hline $\begin{array}{c}\text { Jarak / tinggi ab } \\
(\mathrm{cm})\end{array}$ & $\begin{array}{c}\text { Panjang ac } \\
\text { (cm) }\end{array}$ \\
\hline 100 & 83,900 \\
105 & 88,095 \\
110 & 92,290 \\
115 & 96,485 \\
120 & 100,680 \\
125 & 104,875 \\
130 & 109,070 \\
135 & 113,265 \\
140 & 117,460 \\
145 & 121,655 \\
150 & 125,850 \\
155 & 130,045 \\
160 & 134,240 \\
165 & 138,435 \\
170 & 142,630 \\
175 & 146,825 \\
180 & 151,020 \\
185 & 155,215 \\
190 & 159,410 \\
195 & 163,605 \\
200 & 167,800 \\
\hline &
\end{tabular}

Dari gambar 7 sensor PIR dan sensor ultrasonik ditempatkan pada ketinggian sekitar $110-135 \mathrm{~cm}$, jika data tersebut dihubungkan dengan tabel 3 maka didapat block area deteksi sistem jarak maksimalnya sekitar 92,290 - 113,265 cm. Sehingga hasil akhir dari disain Lampu PJU Otomatis dapat digambarkan seperti pada gambar 8 .

\section{KESIMPULAN}

Dengan menggunakan teknologi tepat guna dapat dibuat lampu Lampu PJU Otomatis berbasiskan teknologi solar sel dan mikrokontroler sehingga dapat membantu pemerintah dalam memberikan solusi energi alternatif dalam mengatasi krisis energi. Hasil pengujian dan perhitungan dengan menggunakan datasheet, sumber data WHO dan rumus segitiga didapatkan disain yang baik dari Lampu PJU Otomatis dengan tinggi tiang PJU 2 meter, letak sensor PIR dan sensor Ultrasonik sekitar $130 \mathrm{~cm}$ dari dasar tiang PJU dan block area yang terdeteksi sistem adalah sekitar $120 \mathrm{~cm}$ (pembulatan dari $109,070 \mathrm{~cm}$ ). Artinya bila ada objek (manusia) dengan jarak maksimum sekitar 109,070 cm sistem akan bekerja dengan baik (menyalakan lampu LED pada kondisi intensitas cahaya kurang/redup atau malam hari). Langkah penyempurnaan perlu dilakukan agar kenyamanan pengguna lampu PJU khususnya yang sering bepergian merasa nyaman saat berada di area sistem, misalnya menambahkan fasiltas charging smartphone di area sistem tersebut.

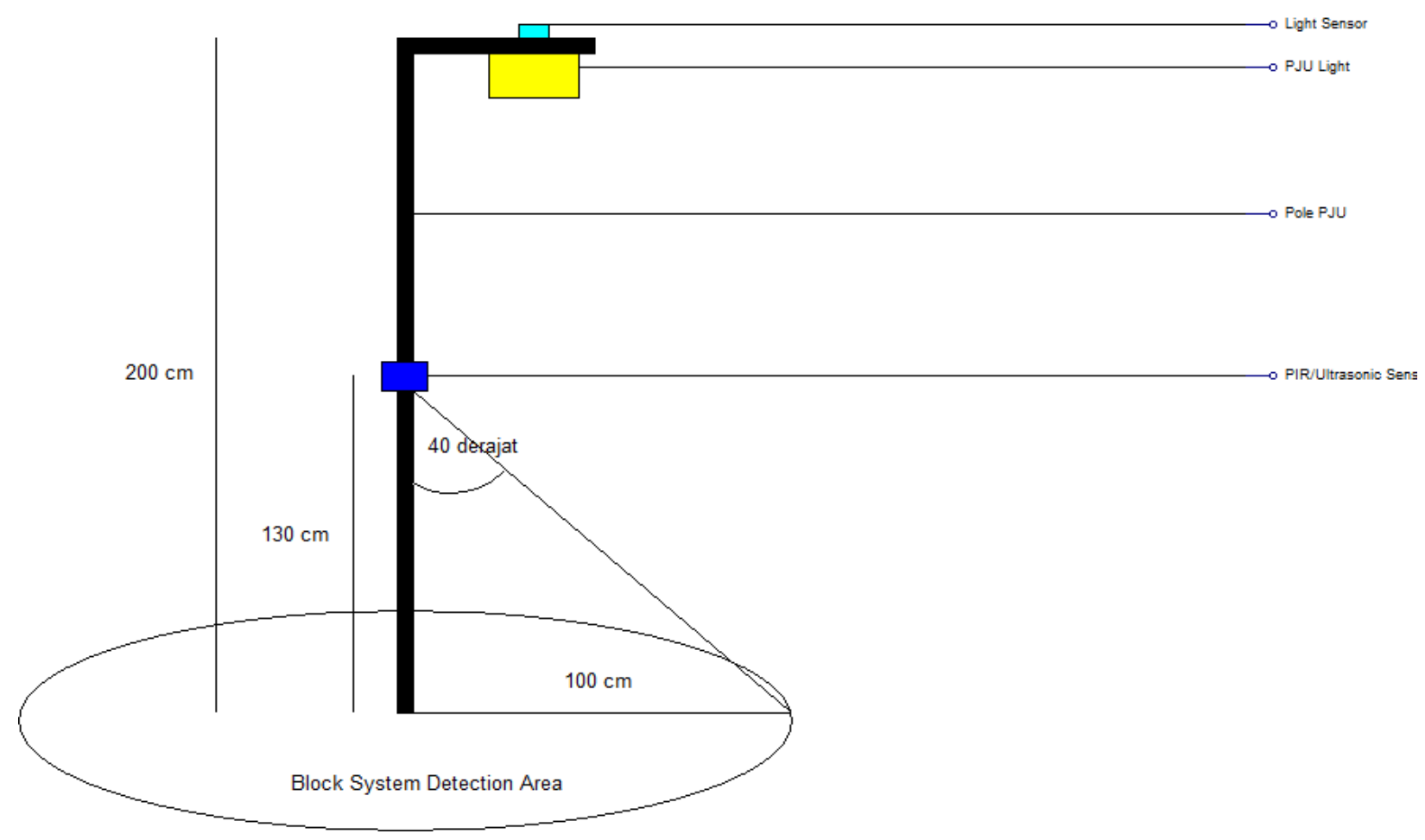

Gambar 8. Disain Lampu PJU Otomatis 


\section{UCAPAN TERIMA KASIH}

Penulis mengucapkan terima kasih kepada Prodi Sistem Komputer Universitas Komputer Indonesia, Direktorat dan Pengabdian Masyarakat, Direktorat Jenderal Penguatan Riset dan Pengembangan, Kementrian Riset Teknologi dan Pendidikan Tinggi sesuai dengan Kontrak Penelitian Tahun Anggaran 2018 Nomor: 023A/SPL/LPPM/UNIKOM/VI/2018.

\section{DAFTAR PUSTAKA}

[1] Sutono, "Menggunakan Sensor Gerak Dan Sensor Cahaya Berbasis Arduino," vol. 12, no. 2, pp. 223232, 2014.

[2] E. A. G. Ade Ramdan, Dicky Rianto Prajitno, Herlan, "LED-based Smart Lamp with Multi Sensor Lampu Pintar Berbasis LED dengan Multi Sensor," $J$. INKOM, 2013.

[3] A. Sittoni, D. Brunelli, D. Macii, P. Tosato, and D. Petri, "Street lighting in smart cities: A simulation tool for the design of systems based on narrowband PLC," in 2015 IEEE 1st International Smart Cities Conference, ISC2 2015, 2015.

[4] A. Florea, A. Farahat, C. Postelnicu, J. L. Martinez Lastra, and F. J. Azcondo Sánchez, "Smart lighting in multipurpose outdoor environments: Energy efficient solution using network of cooperating objects," in CEUR Workshop Proceedings, 2013.

[5] Ying-Wen Bai, Chen-Chien Cheng, and Zi-Li Xie, "Use of ultrasonic signal coding and PIR sensors to enhance the sensing reliability of an embedded surveillance system," in 2013 IEEE International Systems Conference (SysCon), 2013, pp. 287-291.

[6] J. P. Sriwijaya, "Energi Listrik, Penduduk, Ekonomi, Pembangunan, Hemat Energi.," J. Pegabdian Sriwij., 2011.

[7] S. Narayana, R. V. Prasad, V. S. Rao, T. V. Prabhakar, S. S. Kowshik, and M. S. Iyer, "PIR sensors," in Proceedings of the 14th International Conference on Information Processing in Sensor Networks - IPSN '15, 2015.

[8] D. J. Jacob and D. A. Winner, "Effect of climate change on air quality," Atmos. Environ., 2009.

[9] D. Bohn, "Environmental effects on the speed of sound," J. Audio Eng., 1988. 